\title{
EVALUATION OF ANTIBACTERIAL, ANTIMICROBIAL, AND HYPOGLYCEMIC EFFECTS OF THE LEAVES OF EMBELIA RIBES
}

\section{HASEENA BANU H ${ }^{1}$, PRATEEBA MS ${ }^{2}$, PREETHI LOGANATHAN ${ }^{2}$, SUGANTHI SUBRAMANIAM ${ }^{2}$}

${ }^{1}$ Department of Biochemistry, Bhaktavatsalam Memorial College for Women, Korattur, Chennai, Tamil Nadu, India. ${ }^{2}$ Department of Pathology, Dr. ALM P-G IBMS, University of Madras, Taramani Campus, Chennai, Tamil Nadu, India. Email: ssuganthi25032015@gmail.com

\section{Ref-https:/innovareacademics.in/iournals/index.php/ajpcr/article/viewFile/27613/15566}

\section{ABSTRACT}

Objective: The purpose of this work is to evaluate the antimicrobial, antibacterial, and hypoglycemic effects of methanolic and ethanolic extracts of Embelia ribes leaves using in vitro studies.

Methods: Antibacterial activities of the methanolic and ethanolic extract of E. ribes leaves against Escherichia coli, Staphylococcus aureus, Enterococci, and Klebsiella pneumoniae at different concentrations ranging from 10, 25, 50, and $75 \mu \mathrm{g} / \mathrm{mL}$ and their antibacterial activities were compared to those of the reference controls such as ciprofloxacin and clindamycin. Furthermore, the effect of leaf extracts on $\alpha$-amylase and $\alpha$-glucosidase enzymes was assayed.

Results: The methanolic and ethanolic extract of $E$. ribes leaves effectively inhibited the activity of $\alpha$-amylase and $\alpha$-glucosidase in a dose-dependent manner. The effect of the methanolic extract was more prominent than that of ethanolic extract. At the same time, both the extracts showed markable inhibition of bacterial growth at a concentration of $75 \mu \mathrm{g} / \mathrm{mL}$ compared to the other three doses $(10,25$, and $50 \mu \mathrm{g} / \mathrm{ml})$ and also commercially available antibiotic drugs ciprofloxacin and clindamycin that were used as positive control drugs. The antibacterial activity of methanolic extract is significantly higher than that of ethanolic extract.

Conclusion: The preliminary results of this study have put forward E. ribes into promising herb with respect to its therapeutic potential although further studies are needed to evaluate its mechanism of action.

Keywords: $\alpha$-amylase, $\alpha$-glucosidase, Embelia ribes.

Erratum of the manuscript no 27613 published in September 2018 issue.

\section{OLD AFFILIATION}

HASEENA BANU H1, PRATEEBA MS2, PREETHI LOGANATHAN2, SUGANTHI SUBRAMANIAM2

1Department of Biochemistry, Bhaktavatsalam Memorial College for Women, Korattur, Chennai, Tamil Nadu, India. 2Department of Pathology, Dr. ALM P-G IBMS, University of Madras, Taramani Campus, Chennai, Tamil Nadu, India.

\section{NEW CORRECTED AFFILIATION}

HASEENA BANU H1, PRATEEBA MS2, PREETHI LOGANATHAN2, SUGANTHI SUBRAMANIAM2

1Department of Pathology, Dr ALM P-G IBMS, University of Madras, Taramani Campus, Chennai - 600113.

2Department of Biochemistry, Bhaktavatchalam College for Women, Korattur,Chennai.

Email id: haseenabanuh@gmail.com 